\title{
The Effect of Education Given to the Primiparous Pregnant Women on Postpartum Depression
}

\author{
Primipar Gebe Kadınlara Verilen Eğitimin \\ Doğum Sonrası Depresyon Üzerine Etkisi
}

\section{Bahtışen KARTAL, ${ }^{a}$ Nimet KARATAȘ, ${ }^{b}$ Mürüvvet BAȘER ${ }^{c}$}

aDepartment of Gynecology and Obstetrics Nursing,

Gaziosmanpaşa University

Tokat Health School, Tokat

${ }^{b}$ Department of Public Health Nursing, Hacı Bektaş Veli University

Semra and Vefa Küçük Health School, Nevşehir

'Department of Gynecology and

Obstetrics Nursing,

Erciyes University

Faculty of Health Sciences, Kayseri

Geliş Tarihi/Received: 13.05 .2016

Kabul Tarihi/Accepted: 14.11 .2016

Yazışma Adresi/Correspondence: Bahtışen KARTAL

Gaziosmanpaşa University

Faculty of Health Sciences,

Department of Nursing, Tokat,

TÜRKIYE/TURKEY

bahtisen.kartal@gop.edu.tr

This study was presented as an oral presentation at $1^{\text {st }}$ Congress of Childbirth Preparation Training and Trainer, 21-23 September 2012, Izmir, Turkey.

This study was supplied by Scientific Projects Unit of Erciyes University (Project Code: TSD-10-3208).

doi: 10.5336/gynobstet.2016-52028

Copyright $(02016$ by Türkiye Klinikleri

\begin{abstract}
Objective: In order to protect the health of mother and her infant, it is important to prevent postpartum depression, to diagnose it earlier and to supply the necessary treatment. One of the interventions aimed at preventing postpartum depression is education studies. This is a experimental study with control group which was conducted in order to determine the effect of Postpartum Preparedness Education given to the primiparous pregnant women on postpartum depression risk. Material and Methods: The study sample consisted of 182 women (97 in control group and 85 in intervention group). Ethics Committee Approval was acquired for the study and informed consent was obtained from the women. The women in the intervention group were given Postpartum Preparedness Education between the 28th and 32nd gestational weeks. Chi-square, Fisher's Exact, MC Pearson, Student's $t$ and Mann Whitney $U$ tests were used in order to analyze the data. Results: It was determined that total depression score of women in intervention group $(53.0 \pm 16.7)$ is lower than that of women in control group $(61.5 \pm 22.3)$ and the difference between the two groups is significant $(\mathrm{p}<0.05)$. In addition, while there was no significant difference between the two groups in terms of sub dimensions such as selfharm, sleeping and eating disorders $(p>0.05)$, depression score of women in intervention group were much lower in terms of sub dimensions such as mood changes, guiltiness and anxiety $(\mathrm{p}<0.05)$. It was also found that depression scores of women in intervention group who live in rural area, whose education level is secondary school or less, who don't work, who have low-income status and who are 23 years old or younger were lower than those of control group and the difference between the groups was significant $(\mathrm{p}<0.05)$. Conclusion: As a result, it can be said that Postpartum Preparedness Education given to the pregnant women is effective on postpartum depression risk.
\end{abstract}

Key Words: Prenatal care; postpartum period; depression, postpartum

ÖZET Amaç: Annenin ve bebeğin sağlı̆̆ını korumak için doğum sonu depresyonun önlenmesi, erken tanı ve tedavisinin sağlanması önemlidir. Doğum sonu depresyonu önlemeyi amaçlayan müdahalelerden birisi de eğitim çalışmalarıdır. Bu araştırma primipar gebelere, doğum sonu döneme hazırlık eğitiminin doğum sonrası depresyon riski üzerine etkisini değerlendirmek amacıyla yapılmış kontrol gruplu deneysel bir çalışmadır. Gereç ve Yöntemler: Araştırmanın örneklemini kontrol grubunda 97, müdahale grubunda 85 kişi olmak üzere 182 kadın oluşturmuştur. Çalışma için etik kurul onayı ve kadınlardan bilgilendirilmiş onam alınmıştır. Müdahale grubundaki kadınlara gebeliklerinin 28-32. haftalarında doğum sonu döneme hazırlık eğitimi verilmiştir. Verilerin değerlendirilmesinde ki-kare, Fisher, MC Pearson, Student t ve Mann Whitney U testleri kullanılmıştır. Bulgular: Çalışmaya katılan müdahale grubundaki kadınların toplam depresyon puanının $(53,00 \pm 16,70)$ kontrol grubuna $(61,54 \pm 22,33)$ göre daha düşük olduğu, iki grup arasındaki farkın önemli olduğu belirlenmiştir $(\mathrm{p}<0,05)$. Ayrıca kendine zarar verme, uyuma ve yeme bozukluğu alt boyutlarında iki grup arasında bir farklılık görülmezken ( $>0,05)$, duygusal değişkenlik, suçluluk ve anksiyete alt boyutlarında depresyon puanının müdahale grubunda önemli ölçüde düşük olduğu bulunmuştur $(\mathrm{p}<0,05)$. Müdahale grubundaki kadınlardan kırsal bölgede yaşayan, ortaokul ve altı eğitim seviyesine sahip olan, çalışmayan, gelir durumu düşük, 23 yaş ve altında olanların depresyon puanının kontrol grubuna göre daha düşük olduğu ve gruplar arasındaki farkın da önemli olduğu tespit edilmiştir $(\mathrm{p}<0,05)$. Sonuç: Sonuç olarak doğum sonu döneme hazırlık eğitiminin doğum sonrası depresyon riski üzerine etkili olduğu söylenebilir.

Anahtar Kelimeler: Prenatal bakım; postpartum dönem; depresyon, doğum sonrası

Turkiye Klinikleri J Gynecol Obst 2016;26(4):197-204 


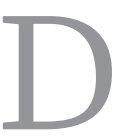

epression seen in postnatal period is a major health problem that adversely affects women's health and that of the family's and the infant's health, too. ${ }^{1,2}$ Postnatal depression may vary from society to society but generally affects $10 \%$ to $15 \%$ of women in postpartum period. In the studies that were carried out in Turkey, it was reported that the incidence of postpartum depression varied between $17 \%$ and $36.9 \%{ }^{3}$

The mothers may feel inadequate in the newborn's and their own care in postpartum period and they can feel fear of failing to fulfil the motherhood role. ${ }^{4,5}$ Especially in primiparous mothers, the lack of knowledge about baby care, baby's growth and development, normal characteristics, behaviour (all night crying, etc.) and diseases causes anxiety, decreases the satisfaction of the role of motherhood, and affects parent-infant attachment and the change of life negatively. Primiparous mothers need information and counselling about self-care, hygiene, sexual life, family planning, baby care and nutrition in postpartum period. If the desired level of health care is not given to mothers, the mother and infant can have physical, psychological and emotional problems. ${ }^{6}$ It has been stated that 30\% of the causes of postpartum depression seen in the first three months of postpartum are based on difficulties related to baby care. ${ }^{6}$ In a study by Vural and Akkuzu, it was pointed out that the mothers who had difficulty caring for themselves and their babies in postpartum period suffered more from depression $(35.5 \%){ }^{4}$

The educational needs of primiparous pregnant women who consulted health care providers for antenatal care should be identified and they should be prepared for postpartum period. It is thought that the Postpartum Preparedness Education that will be given to primiparous pregnant women by nurses will make the mothers feel competent in both their own care and their baby's care, thus it will be an attempt to prevent mental health problems that will be seen in postpartum period.

The purpose of the study: This is a control group experimental study which was conducted in order to determine the effect of Postpartum Preparedness Education given to the primiparous pregnant women on postpartum depression risk.

\section{MATERIAL AND METHODS}

This study was conducted with mothers and pregnant women registered to 6 different family health centres in city in the Inner Anatolia Region of Turkey. The data (mean score of depression) obtained from "The Postpartum Depression Screening Scale: Its Reliability and Validity for the Turkish Population" were used in order to determine the size of sampling. ${ }^{7,8}$ Assuming that mean score of depression will be reduced by 10 points (from 60 to 50) it was calculated that minimum 64 people were necessary to form a representative sample ( $\alpha=0.05, \beta=0.20)$. 97 women were included for each group considering unexpected losses.

\section{DATA COLLECTION TOOLS}

The data were collected by using "Introductory Form", "Postpartum Introductory Form" and "Postpartum Depression Screening Scale”.

Introductory Form (IF): This form is composed of questions that have been developed by the researchers themselves to determine pregnant women / mothers' demographic and obstetric characteristics and their marital relationships.

Postpartum Introductory Form (PIF): This form was prepared by the researchers themselves in order to determine the obstetric and infant characteristics and health problems of their own and their infants during postpartum period. This form was applied between the $4^{\text {th }}$ and $6^{\text {th }}$ weeks postpartum.

Postpartum Depression Screening Scale (PDSS): PDSS is a scale developed by Beck and Gable and validity and reliability analyses were done by Karaçam and Kitiş in Turkey. ${ }^{7-9}$ This is a five-point Likert scale ranging from 1 (strongly disagree) to 5 (strongly agree) and it contains 35 items and 7 dimensions (5 items for each dimension). The Turkish version of the scale consists of 6 sub-dimensions. Each item describes the feelings of the mother after the birth. The women were wanted 
to mark the choice that best describes their feelings for the last two weeks for each item. The possible lowest score is 35 and the possible highest score is 175 for the scale. ${ }^{7,8}$ The Cronbach's Alpha reliability score was 0.95 in this study.

\section{POSTPARTUM PREPAREDNESS EDUCATION}

The aim of postpartum preparedness education was to prepare primipara pregnant women for the conditions that they may experience in the postpartum period and to prevent the risk of postpartum depression that may develop due to lack of knowledge. This education included postpartum personal care and baby care. The education took about 90 minutes.

\section{DATA COLLECTION}

Pregnant women/ mothers who are over 18 years old, primipara, literate, married, have a live singleton pregnancy, have no risk factors in their pregnancies (heart disease, placenta previa, oligohydramnios, preeclampsia, diabetes, epilepsy), have a healthy new-born, agreed to participate in the study, don't have a diagnosed mental illness, pregnant by natural means, didn't have a situational crisis such as bereavement, accident, immigration etc. and not health care providers have been included in the study.

The data of the control group (CG) were collected primarily in order to prevent interference between the intervention and control groups and to have healthy results.

No intervention or application was done on mothers in CG by the researchers other than routine approaches and applications in hospitals and Family Health Centres. IF, PIF and PDSS were applied between the $4^{\text {th }}$ and $6^{\text {th }}$ weeks postpartum.

Pregnant women in the Intervention Group (IG) were given "Postpartum Preparedness Education". After the education, a booklet containing the content of education was given to each pregnant woman to ensure that they remember the education later. IF, PIF and PDSS were applied between the 4th and 6th weeks postpartum. Four of the women were removed from the study because three had problems with their husbands and one had an infant with congenital defect. Eight of the women couldn't be reached during the postpartum period. The study was completed with 85 women in the IG (Figure 1).

\section{DATA EVALUATION}

The data were evaluated by a computer. Normal distribution of quantitative data was confirmed with the One-Sample Kolmogorov-Smirnov test. Parametric tests were used for normally distributed data and non-parametric tests were used for non-normally distributed data. Introductory information was presented in tables as numbers and percentage distributions. In addition to medians, averages were given with standard deviation. While evaluating the obtained data, Chi-square, Fisher, MC Pearson Chi-square and Student's t tests were used to test the difference between groups and Chi-square and Mann-Whitney U tests were used to compare the two groups. A value of $p<0.05$ was considered significant for all comparisons.

\section{ETHICAL MATTERS}

This study was conducted with the prior approval of the Ethics Committee of Erciyes University Faculty of Medicine. The written permissions of Local Health Authority and Central City Community Health Centre were also obtained. The participants were provided information about the study and their informed consent was obtained.

\section{RESULTS}

It was found out that the average age of women in the IG participated in the study was $23.3 \pm 3.8$ years, $34.1 \%$ of them worked, $60.0 \%$ of them lived in the city centre, $31.8 \%$ of them had high school education and $49.4 \%$ of them had moderate income. In the CG, the average age of women was $23.3 \pm 3.9$ years, $17.5 \%$ of them worked, $56.7 \%$ of them lived in the city centre, $38.1 \%$ of them had high school education and $56.7 \%$ of them had moderate income. The study groups weren't similar in terms of work status $(p<0.05)$, but they were found to be similar in terms of other features ( $p>0.05)$. In addition, while $76.3 \%$ of the women in the CG 


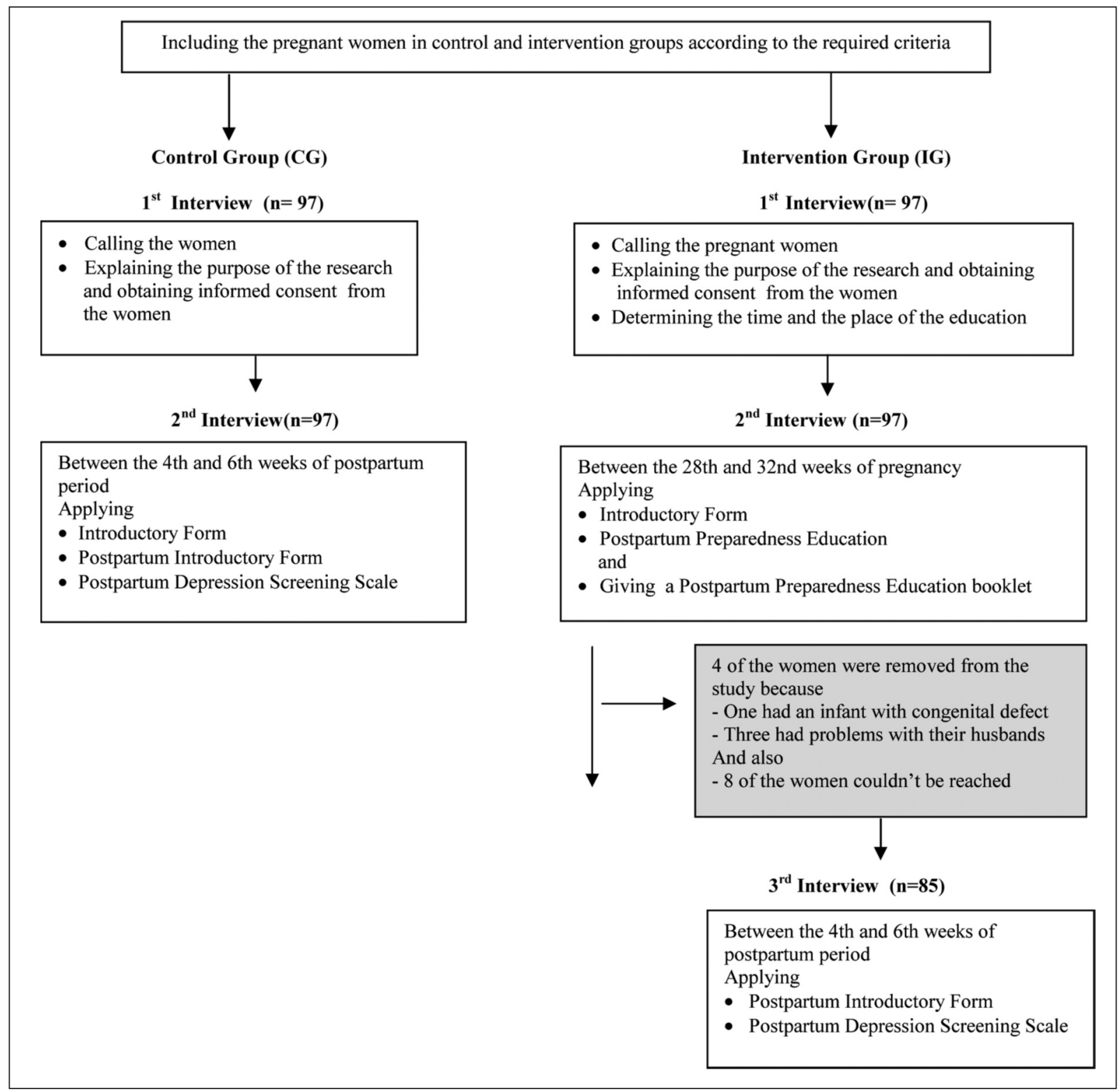

FIGURE 1: Study design.

planned pregnancy and $49.5 \%$ of them gave birth by caesarean section, $83.5 \%$ of the women in the IG planned pregnancy and $50.6 \%$ of them gave birth by caesarean section ( $p>0.05)$.

Table 1 shows postpartum health problems of the mothers. That the majority of mothers in both groups experienced postpartum health problems (CG $=71.1 \%, \mathrm{IG}=70.6 \%$ ) will be seen in the table ( $p>0.05)$. Nipple cracks and pain were mostly stated postpartum health problems in both groups. In addition, while fatigue-insomnia (72.5\%) ranked sec- ond among the women in the CG, constipation / haemorrhoids $(60.0 \%)$ ranked second in the IG in terms of incidence.

The kinds of the health problems that the infants have were given in Table 2. It was determined that the majority of the infants in both groups experienced health problems $(\mathrm{F}=85.6 \%-\mathrm{M}=84.7 \%$; $p>0.05)$. Gas pains was the mostly stated problem ( $C G=72.3 \%$ - IG $=69.4 \%$ ) by the mothers and the second mostly stated problem was icterus $(\mathrm{CG}=$ $50.6 \%-\mathrm{IG}=52.8 \%$ ). 
TABLE 1: Postpartum health problems of the mothers.

\begin{tabular}{|c|c|c|c|c|}
\hline \multirow[b]{2}{*}{ Health problems in the postpartum period } & \multicolumn{2}{|c|}{$\begin{array}{l}\text { Control group (CG) } \\
\qquad(n=97)\end{array}$} & \multicolumn{2}{|c|}{$\begin{array}{l}\text { Intervention group (IG) } \\
\qquad(\mathrm{n}=85)\end{array}$} \\
\hline & $\mathrm{n}$ & $\%$ & $\mathrm{n}$ & $\%$ \\
\hline Mothers that have health problems & 69 & 71.1 & 60 & 70.6 \\
\hline Mothers that don't have health problems & 28 & 28.9 & 25 & 29.4 \\
\hline$p=0.936$ & & \multicolumn{3}{|c|}{$X^{2}=0.007$} \\
\hline \multicolumn{5}{|l|}{ The kind of health problem $(n=69 / 60)$ * } \\
\hline Pain / infection in the sewing area & 23 & 33.3 & 31 & 51.7 \\
\hline Breast infection & 11 & 15.9 & 7 & 11.7 \\
\hline Painful cracked nipples & 52 & 75.4 & 43 & 71.6 \\
\hline Urinary tract infection & 13 & 18.8 & 7 & 11.7 \\
\hline Fear of failing to fulfil the role of motherhood & 22 & 31.8 & 5 & 8.3 \\
\hline Fatigue, insomnia & 50 & 72.5 & 33 & 55.0 \\
\hline Constipation / / haemorrhoids & 27 & 39.1 & 36 & 60.0 \\
\hline Small and receding nipple & 16 & 23.2 & 8 & 13.3 \\
\hline Insufficient milk / early discontinuation of milk production & 18 & 26.1 & 8 & 13.3 \\
\hline Feeling insufficient in the new-born's and their own care & 7 & 10.1 & 3 & 5.0 \\
\hline
\end{tabular}

*More than one answer was given.

\begin{tabular}{|c|c|c|c|c|}
\hline \multirow[b]{2}{*}{ Health problems of the infant } & \multicolumn{2}{|c|}{$\begin{array}{l}\text { Control Group (CG) } \\
\qquad(\mathrm{n}=97)\end{array}$} & \multicolumn{2}{|c|}{$\begin{array}{l}\text { Intervention Group (IG) } \\
\qquad(\mathrm{n}=85)\end{array}$} \\
\hline & $\mathrm{n}$ & $\%$ & $\mathrm{n}$ & $\%$ \\
\hline Have problems & 83 & 85.6 & 72 & 84.7 \\
\hline \multirow[t]{2}{*}{ Don't have problems } & 14 & 14.4 & 13 & 15.3 \\
\hline & \multicolumn{2}{|c|}{$X^{2}=0.027$} & \multicolumn{2}{|c|}{$p=0.870$} \\
\hline \multicolumn{5}{|c|}{ The kind of health problem $(n=83 / 72)$ * } \\
\hline Sucking problems & 29 & 34.9 & 12 & 16.7 \\
\hline Rash & 24 & 28.9 & 20 & 27.8 \\
\hline Diarrhoea & 9 & 10.8 & 5 & 6.9 \\
\hline Icterus & 42 & 50.6 & 38 & 52.8 \\
\hline Eye infection & 15 & 18.1 & 3 & 4.2 \\
\hline Inadequate weight gain & 2 & 2.4 & 4 & 5.5 \\
\hline Restlessness & 16 & 19.3 & 25 & 34.7 \\
\hline Umbilical infection & 8 & 9.6 & 8 & 11.1 \\
\hline Disorder in sleep patterns & 23 & 27.7 & 20 & 27.8 \\
\hline Gas pain & 60 & 72.3 & 50 & 69.4 \\
\hline Moniliasis & 15 & 18.1 & 8 & 11.1 \\
\hline Constipation & 3 & 3.6 & 6 & 8.3 \\
\hline
\end{tabular}

*More than one answer was given.

Table 3 shows the distribution of the average of the scores that women who participated in the study got from PDSS and its sub-dimensions. While the mean depression score was $61.5 \pm 22.3$ in the
CG, it was $53.0 \pm 16.7$ in the IG $(p<0.05)$. In addition, it was determined that depression scores in the IG were also lower in terms of mood changes, guiltiness and anxiety sub-dimensions $(p<0.05)$. 
TABLE 3: The distribution of the average of the scores that women got from postpartum depression screening scale and its sub-dimensions.

\begin{tabular}{|c|c|c|c|c|}
\hline PDSS Score/Sub-dimension Score & 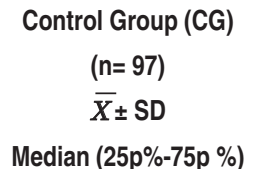 & $\begin{array}{l}\text { Intervention Group (IG) } \\
\qquad \begin{array}{l}(\mathrm{n}=85) \\
\bar{X}_{ \pm} \mathrm{SD}\end{array} \\
\text { Median }(25 \mathrm{p} \%-75 \mathrm{p} \%)\end{array}$ & U & $\mathrm{p}$ \\
\hline Total Score & $\begin{array}{c}61.5 \pm 22.3 \\
57.00(45.00-73.00)\end{array}$ & $\begin{array}{c}53.0 \pm 16.7 \\
47.00(41.00-61.00)\end{array}$ & 3148.00 & 0.006 \\
\hline Mood Changes & $\begin{array}{c}21.0 \pm 8.1 \\
20.00(14.00-25.50)\end{array}$ & $\begin{array}{c}17.4 \pm 7.1 \\
15.00(11.00-22.50)\end{array}$ & 2892.50 & 0.000 \\
\hline Self-harm & $\begin{array}{c}15.3 \pm 6.8 \\
12.00(11.00-20.50)\end{array}$ & $\begin{array}{c}13.4 \pm 3.8 \\
11.00(11.00-14.00)\end{array}$ & 3636.00 & 0.141 \\
\hline Sleeping Disorder & $\begin{array}{c}6.9 \pm 3.5 \\
6.00(4.00-8.50)\end{array}$ & $\begin{array}{c}7.2 \pm 3.3 \\
6.00(4.00-8.50)\end{array}$ & 3846.50 & 0.424 \\
\hline Guiltiness & $\begin{array}{c}5.2 \pm 2.8 \\
4.00(3.00-6.00)\end{array}$ & $\begin{array}{c}4.3 \pm 2.1 \\
3.00(3.00-5.50)\end{array}$ & 3326.50 & 0.014 \\
\hline Eating Disorder & $\begin{array}{c}6.0 \pm 3.1 \\
6.00(3.00-7.00)\end{array}$ & $\begin{array}{c}5.1 \pm 2.6 \\
4.00(3.00-7.00)\end{array}$ & 3459.50 & 0.053 \\
\hline Anxiety & $\begin{array}{c}7.1 \pm 2.9 \\
7.00(5.00-9.00)\end{array}$ & $\begin{array}{c}5.7 \pm 2.7 \\
5.00(3.00-7.00)\end{array}$ & 2925.00 & 0.001 \\
\hline
\end{tabular}

It was also found that depression scores of women in IG who live in rural area, whose education level is secondary school or less, who don't work, who live in a nuclear family, who have lowincome status and who are 23 years old or younger are lower than those of CG and the difference between the groups is significant $(p<0.05)$.

\section{DISCUSSION}

Postnatal depression affects the harmony between spouse, children's cognitive, physical, and emotional development negatively as it affects the mothers' health. ${ }^{10,11}$ The information provided to the women about their own care and baby care in the postpartum period, reduces the anxiety of a mother with a new baby and may increase feelings of competence. ${ }^{12}$ Educational programs to prevent postpartum depression aim to prepare mothers for the postpartum period and reduce the impact of psycho-social risk factors. ${ }^{13}$ In this study, it was found that total depression score of women in IG $(53.00 \pm 16.70)$ was significantly lower than total depression score of women in CG $(61.5 \pm 22.3)$, $(p<0.05$; Table 3$)$. Two similar studies were found in the literature. Matthey et al. determined that the education given to women reduced postpartum depression. ${ }^{14}$ Buist et al. also found out that the education reduced postpartum anxiety, but this reduction wasn't significant statistically. ${ }^{13}$

The symptoms of postpartum depression are crying spells, anxiety, agitation, mood changes, pessimism, inability to care for the newborn and feeling guilty about her maternal ability. ${ }^{15,16}$ It was determined that the depression score of IG was significantly lower than the depression score of CG in terms of mood changes, guiltiness and anxiety subdimensions $(p<0.05$; Table 3$)$. Similar to this result, Matthey et al. stated that education reduced postpartum depression in their study to determine the effect of education which was given to primiparous women and their partners on postpartum depression and stress. ${ }^{14}$

Other symptoms of postpartum depression include sleeping and eating disorders. ${ }^{15}$ However, it can be difficult to distinguish these symptoms of postpartum depression from involutional normal phenomenon (weight loss, insomnia and etc.). ${ }^{10,17}$ Women frequently wake up to meet the needs of 
their infants, so they may suffer from insomnia. Sleep disorders can even trigger the emergence of depressive symptoms. ${ }^{1}$ Therefore; these findings are required to be supported with other depression findings. In this study, no significant difference was observed between IG and CG in terms of sub-dimensions of sleeping and eating disorders $(p>0.05$; Table 3).

It is reported that women with postpartum depression can think of harming themselves and their infant more and the risk of suicide is greatest for them. ${ }^{18}$ In a study conducted, it was found that $9 \%$ of women with postpartum depression had thought of committing suicide. ${ }^{19}$ In this study, sub-dimension of self-harm in the IG $(13.4 \pm 3.8)$ was lower than the CG $(15.3 \pm 6.8)$, but no statistically significant difference was found between the two groups ( $p>0.05$; Table 3 ). Although not statistically significant, this finding is important because it shows that the education given to primiparous pregnant women reduced the idea of self-harm which is one of the most important ${ }^{1}$ and irreversible results of depression.

The postpartum period is a period that necessitates parents to give baby care, to create a secure environment for the baby, to communicate with the baby, to learn their new roles, to improve family sensitivity, to deal with problems related to the baby.$^{20}$ During this period, the mother's perception of insufficiency may pose a risk for postpartum depression. It is stated that $30 \%$ of the reasons for the mothers to have postpartum depression in the first three months of postpartum period are due to the difficulties related to taking care of the baby. ${ }^{6}$ According to a study by Vural and Akkuzu, the mothers who have difficulty caring for themselves and their babies in postpartum period suffer more from depression (35.5\%). ${ }^{4}$ It was determined in this study that the women in CG had felt the fear of failing to fulfil the motherhood role 4 times more and had felt themselves inadequate in the newborn's and their own care 2 times more than the women in the IG (Table 1). It can be said that the education given to the women in IG reduces the fear of failing to fulfil the motherhood role and concerns about the care of the baby which are ef- fective factors in the development of postpartum depression.

Low level of education, poverty and being at a young age are seen among the causes of postpartum depression. ${ }^{2,15,16}$ The relation between postpartum depression and employment status and family structure is not clear. ${ }^{21-23}$ In this study, it was found that depression scores of women in IG who live in rural area, whose education level is secondary school or less, who live in a nuclear family, who don't work, who have low-income status and who are 23 years old or younger were lower than those of CG and the difference between the groups was significant $(p<0.05)$. In the study of Crockett et al. which was done with women who have low-income status and live in rural areas, a decrease in symptoms of postpartum depression and better adaptation to postpartum period was determined in the intervention group, but the result was not statistically significant. ${ }^{24}$ In a study by Tezel, it was found that education given to prevent postpartum depression is more effective on women with lowincome status. ${ }^{25}$

In the postpartum period, as well as adapting to the changes in themselves, the mothers may have to deal with their own and their baby's health problems that may occur. ${ }^{20}$ These health problems increase hospitalization, decrease the mother's quality of life and make it difficult to cope with her new situation when it is combined with the responsibility of a new baby. ${ }^{26,27}$ Her own or her baby's health problems can increase the mother's anxiety and can lead to more difficulties in her own and her baby's care. In this study, the mothers in both groups stated that they experienced almost the same level of health problems in themselves and their babies (Table 1, 2). In addition, the visibility percentage of preventable health problems of babies such as eye infection and moniliasis was higher and sucking problems were seen two times more in CG than in IG (Table 2). It can be said that Postpartum Preparedness Education given to IG is effective. This result is significant because it supports the purpose of the education. 
As a result, it was determined that Postpartum Preparedness Education given to primiparous pregnant women decreased the mean score of postpartum depression.

\section{Acknowledgement}

We thanks to Şefik Kartal for english-translation of our article; thanks to Prof.Dr. Osman Günay and Ass.Prof.Dr. Aylin Alkaya for statistical analyses.

\section{REFERENCES}

1. Tezel A, Gözüm S. [Depressive symptoms which might be seen in postpartum period in women and nursing care]. Journal of Hacettepe University School of Nursing 2005:62-8.

2. Sünter $A T$, Güz $H$, Canbaz $S$, Dündar $C$. [Postpartum depression in Turkey: prevalence and related factors]. J Turk Obstet Gynecol 2006;3(1):26-31.

3. Gölbaşı Z. [Postpartum psychiatric problems]. Şirin A, Kavlak O, editörler. Kadın Sağlı̆ı. 1. Baskı. İstanbul: Bedray Basın Yayıncıık; 2008. p.805-8.

4. Vural G, Akkuzu G. [Determined the depression prevalance of moters given normal vajinal birth on the tenth day of their post-partum period]. C.Ü. Hemşirelik Yüksekokulu Dergisi 1999;3(1):33-8.

5. Bilszta J, Ericksen J, Buist A, Milgrom J. Women's experience of postnatal depressionbeliefs and attitudes as barriers to care. Aust J Adv Nurs 2010;27(3):44-54.

6. Yıldız D. [Counselling needs and interventions of mothers about infant care during postpartum period]. Gulhane Med J 2008;50(4):294-8.

7. Karaçam Z, Kitiş Y. [The Postpartum Depression Screening Scale: its reliability and validity for the Turkish population]. Turk Psikiyatri Derg 2008;19(2):187-96.

8. Karaçam Z, Öner H. [Calculation of cut off points in the Turkish version of postpartum depression screening scale]. Atatürk Üniversitesi Hemşirelik Yüksekokulu Dergisi 2008;11(2): 61-71.

9. Beck CT, Gable RK. Postpartum Depression Screening Scale: development and psychometric testing. Nurs Res 2000;49(5):27282.
10. Jardri R, Maron M. Why and how to improve postnatal depression screening in the immediate post-partum? Clin Effect Nurs 2006; 9(2):238-41.

11. Mallikarjun PK, Oyebode F. Prevention of postnatal depression. J R Soc Promot Health 2005;125(5):221-6.

12. Arslan $F$, Uzun Ş. [Examination of the postnatal education and counselling services of nurses: medical education]. Turkiye Klinikleri J Med Sci 2008;28(5):736-42.

13. Zinga D, Phillips SD, Born L. [Postpartum depression: we know the risks, can it be prevented?]. Rev Bras Psiquiatr 2005;27 Suppl 2:S56-64.

14. Matthey S, Kavanagh DJ, Howie P, Barnett B, Charles M. Prevention of postnatal distress or depression: an evaluation of an intervention at preparation for parenthood classes. J Affect Disord 2004;79(1-3):113-26.

15. Nur N, Cetinkaya S, Bakır DA, Demirel Y. [Prevalence of postnatal depression and risk factors in women in Sivas city]. C.Ü. Tıp Fakültesi Dergisi 2004;26(2):55-9.

16. Özdemir S, Marakoğlu K, Çivi S. [Risk of postpartum depression and affecting factors in Konya center]. TAF Prev Med Bull 2008;7(5): 391-8.

17. Kara B, Çakmaklı $P$, Nacak E, Türeci F. [Postpartum depression]. STED 2001;10(9):333-4.

18. Yıldııım A, Hacıhasanoğlu R, Karakurt P. [The relationship between postpartum depression and social support and affecting factors]. Journal of Human Sciences 2011;8(1):31-46.

19. Howard LM, Flach C, Mehay A, Sharp D, Tylee A. The prevalence of suicidal ideation by the Edinburgh Postnatal Depression Scale in postpartum women in primary care: findings from the RESPOND trial. BMC Pregnancy Childbirth 2011;11:57.

20. Beydağ KD. [Adaptation to motherhood in the postpartum period and the nurse's role]. TAF Prev Med Bull 2007;6(6):479-84.

21. Atasoy N, Bayar Ü, Sade H, Konuk N, Atik L, Barut A, et al. [Clinical and sociodemographic risk factors effecting level of postpartum depressive symptoms during postpartum period]. Turkiye Klinikleri J Gynecol Obst 2004;14(5): 252-7.

22. Ocaktan E, Çalıșkan D, Öncü B, Özdemir O, Köse K. Antepartum and postpartum depression in a primary health care center area. Journal of Ankara University Faculty of Medicine 2006;59(4):151-7.

23. Önen RF, Kaptanoğlu C, Seber G. [Depression prevalence in women and relationship with the risk factors]. Kriz Dergisi 1995;3(12):88-103.

24. Crockett K, Zlotnick C, Davis M, Payne N, Washington $\mathrm{R}$. A depression preventive intervention for rural low-income African-American pregnant women at risk for postpartum depression. Arch Womens Ment Health 2008;11(5-6):319-25.

25. Tezel A. Postpartum Depresyon Riskli Kadınlarda Bakım ve Eğitimin Depresyon Belirti Düzeyine Etkisinin Karşılaştırıması. Erzurum: Halk Sağı̆ı̆ı Hemşireliği Anabilim Dalı Atatürk Üniversitesi Sağlık Bilimleri Enstitüsü; 2003. p.127.

26. Efe ŞY, Taşkın L, Eroğlu K. [Postnatal depression and effecting factors in Turkey]. J Turk Ger Gynecol Assoc 2009;10:14-20.

27. Akdolun Balkaya N. [Care needs of mothers in postpartum period and the role of the midwife and nurse]. C.Ü. Hemşirelik Yüksekokulu Dergisi 2002;6(2):42-9. 